\title{
Implementasi Kurikulum Tingkat Satuan Pendidikan (KTSP) Bahasa Arab Di MAN Tembilahan Indragiri Hilir Riau
}

\author{
Nur Komariah, M.Pd.I
}

\begin{abstract}
KTSP is the result of innovation from KBK. In the KTSP the teacher have to reach the professionalism of listening competence, speakng competence, reading competence, and writing competence, that supported with the creation of an active environment, creative, effective and fun. Islamic Junior High School of Tembilahan is one of the school that teach Arabic and implemented the KTSP but in the implementation there are some competencies that have not owned by their students. This is due to the background of Arabic language teachers who are not of Arabic language teacher education plus the background of the different students differently. This is because of the education background of the teacher was not from Arabic education and also the background of the students was different.
\end{abstract}

\section{Pendahuluan}

Perubahan kurikulum dari KBK kedalam KTSP merupakan salah satu bentuk usaha yang dilakukan oleh pemerintah untuk memecahkan persoalan pendidikan di Indonesia, akan tetapi dalam pelaksanaannya masih ditemukan kelemahan dan kekurangan dalam penyelenggaraan pendidikan, baik di tingkat dasar, menengah, maupun dijenjang pendidikan tinggi. Salah satu kekurangan atau kelemahan yang mendasar terlihat pada implementasi kurikulum, dimana guru merupakan implementator kurikulum, hal ini mengindikasikan bahwa kemampuan dan keterampilan guru selaku implementator kurikulum dianggap belum maksimal dan masih perlu ditingkatkan agar mereka dapat mengembangkan tugas dan tanggung jawab selaku implementator kurikulum yang baik.

Madrasah Aliyah Negeri (MAN) Tembilahan Indragiri Hilir Riau merupakan salah satu madrasah yang menggunakan KTSP. Salah satu mata pelajaran yang diajarkan di MAN Tembilahan adalah bahasa Arab. Berdasarkan observasi penulis di MAN Tembilahan kelas XI MAK guru bahasa Arab menggunakan KTSP untuk pembe- 
lajaran bahasa Arab, akan tetapi terlihat terdapat kompetensi bahasa Arab yang belum dimiliki anak didik seperti berbicara dengan bahasa Arab praktis dan menulis bahasa Arab dengan metode imla' dan dalam kegiatan belajar dan mengajar guru bahasa Arab terlihat tidak menggunakan media dan metode pembelajaran yang variatif, guru terlihat sering menggunakan metode qira'ah, ceramah, qowa'id wa tarjamah, dan latihan-latihan serta penilaian bahasa Arab yang terlihat menekankan kemampuan membaca dan kognitif bukan pada pencapaian empat kompetensi yakni kompetensi menyimak, kompetensi berbicara, kompetensi membaca dan kompetensi menulis. ${ }^{1}$

Selain data di atas berdasarkan observasi penulis diketahui bahwa labor bahasa di MAN Tembilahan Indragiri Hilir Riau tidak dapat berfungsi secara optimal sebagai media pembelajaran bahasa Arab dan dalam kegiatan belajar dan mengajar bahasa Arab guru bahasa Arab sering menggunakan media papan tulis, spidol, buku 2. قاموس محمود يونس dan تعليم اللغة العربية

Berdasarkan data di atas diketahui bahwa implementasi KTSP bahasa Arab di MAN Tembilahan masih ditemukan hal-hal yang dipertanyakan yaitu:

1. Belum terciptanya lingkungan pembelajaran bahasa Arab yang aktif, kreatif, efektif, dan menyenangkan dengan menciptakan kegiatan pembelajaran bahasa Arab yang dapat mendukung tercapainya kompetensi berbahasa Arab.

2. Siswa terlihat tidak menguasai bahasa Arab praktis dan menggunakannya sebagai alat komunikasi di dalam kegiatan belajar dan mengajar bahasa Arab.

3. Siswa terlihat kurang menguasai menulis bahasa Arab dengan metode imla'.

4. Penggunaan metode pembelajaran yang monoton yakni guru terlihat menggunakan metode yang sama dalam beberapa pertemuan seperti metode qira'ah, ceramah, qowa'id wa tarjamah dan latihan-latihan.

5. Pelaksanaan penilaian pembelajaran bahasa Arab terlihat menekankan pada kemampuan kognitif tanpa menekankan

1 Observasi, 14 Juli 2013

2 Observasi, 14 Juli 2013 
pada ke-empat kompetensi berbahasa seperti kompetensi berbicara dengan bahasa Arab praktis dan kompetensi menulis bahasa Arab dengan metode imla'.

Berkenaan dengan hal-hal yang dipertanyakan di atas, maka penulis berkeinginan untuk meneliti berbagai faktor yang menimbulkan implementasi KTSP bahasa Arab di MAN Tembilahan tidak efektif, dan dengan penelitian ini dapat dicarikan solusi sebagai implementasi tersebut dapat meningkatkan keberhasilan pendidikan bahasa Arab di MAN Tembilahan Indragiri Hilir Riau.

\section{Masalah, Tujuan Dan Kegunaan Penelitian A. Masalah}

1. Bagaimana implementasi KTSP Bahasa Arab dilakukan oleh guru bahasa Arab di MAN Tembilahan Indragiri Hilir Riau?

2. Apa faktor-faktor yang ditemukan oleh guru bahasa Arab dalam mengimplementasikan KTSP bahasa Arab di MAN Tembilahan Indragiri Hilir Riau?

3. Upaya apa yang telah dilakukan guru bahasa Arab untuk mengefektifkan implementasi KTSP bahasa Arab di MAN Tembilahan Indragiri Hilir Riau?

\section{B. Tujuan}

Tujuan penelitian ini adalah untuk menjawab tiga rumusan masalah sebagaimana telah dipaparkan di atas. Adapun tujuan penelitian adalah:

1. Untuk mendapatkan informasi tentang bagaimana implementasi KTSP bahasa Arab dilakukan oleh guru bahasa Arab di MAN Tembilahan Indragiri Hilir Riau.

2. Untuk mendapatkan infomasi tentang apa faktor-faktor yang ditemukan oleh guru bahasa Arab dalam mengimplementasi KTSP bahasa Arab di MAN Tembilahan Indragiri Hilir Riau.

3. Untuk mendapatkan informasi tentang apa saja upaya yang telah dilakukan guru bahasa Arab untuk mengefektifkan implementasi KTSP bahasa Arab di MAN Tembilahan Indragiri Hilir Riau. 


\section{Kegunaan}

1. Secara praktis, berguna bagi guru bahasa Arab untuk mengembangkan KTSP dalam menciptakan lingkungan pembelajaran yang aktif, kreatif, efektif dan menyenangkan demi tercapainya tujuan pembelajaran bahasa Arab. Bagi kepala sekolah menjadi masukan guna peningkatan pelaksanaan kegiatan pembelajaran di MAN Tembilahan Indragiri Hilir Riau. Bagi Departemen Agama (DEPAG) berguna guna menganalisis pelaksanaan KTSP di masing-masing daerah maupun jenjang pendidikan.

2. Secara teoritis, penelitian ini merupakan sumbangan pemikiran dan masukan dalam upaya pengembangan ilmu bahasa Arab kaitannya dengan implementasi KTSP di MAN Tembilahan Indragiri Hilir Riau. Disamping itu penelitian ini juga diharapkan dapat menjadi input untuk menambah koleksi khazanah kepustakaan di IAIN STS Jambi, dan diharapkan bisa menjadi bahan acuan bagi peneliti lainnya dalam mengkaji pelaksanaan kurikulum secara umum di tanah air. Selain itu bagi peneliti penelitian ini merupakan pengalaman yang berharga untuk memperluas cakrawala pemikiran dan memperluas wawasan.

\section{Kerangka Pemikiran Dan Metode Penelitian}

\section{A. Kerangka Pemikiran}

1. KTSP Sebagai Inovasi Kurikulum

Perubahan kurikulum atau disebut juga dengan inovasi kurikulum merupakan suatu pembaharuan atau gagasan yang diharapkan membawa dampak terhadap kurikulum itu sendiri. Menurut Wina Sanjaya bahwa inovasi kurikulum adalah "suatu ide, gagasan atau tindakan-tindakan tertentu dalam bidang kurikulum dan pembelajaran yang dianggap baru untuk memecahkan masalah pendidikan." ${ }^{3}$

Diantara bentuk inovasi pada KTSP Bahasa Arab adalah pada dokumen kurikulum, pada KBK untuk setiap pelajaran hanya memuat pendahuluan yang meliputi: rasional, penger-

3 Wina Sanjaya, Kurikulum dan Pembelajaran (Jakarta: Kencana, 2008), hal. 317. 
tian, fungsi dan tujuan, ruang lingkup mata pelajaran, Standar Kompetensi (SK), Kompetensi Dasar (KD), dan materi pokok. Sementara dalam KTSP setiap mata pelajaran hanya dicantumkan: latar belakang, tujuan, ruang lingkup, SK dan KD, silabus KBK/KTSP. ${ }^{4}$ Selain itu pada KTSP pelajaran bahasa arab telah berdiri sendiri dengan pelajaran PAI. ${ }^{5}$

Di dalam KTSP pelajaran bahasa Arab sebagaimana pelajaran bahasa Asing lainnya seperti bahasa Inggris dan Jepang yaitu mengembangkan keterampilan berkomunikasi lisan dan tulisan untuk memahami dan mengungkapkan informasi, pikiran, perasaan, serta mengembangkan ilmu pengetahuan, teknologi dan budaya. Karena bahasa Arab sesuai dengan fungsinya sebagai alat untuk menyampaikan dan menyerap gagasan-gagasan, pikiran, pendapat, dan perasaan baik secara lisan, maupun tulisan.

2. KTSP Sebagai Dokumen Kurikulum

\section{a. Struktur KTSP Dokumen Satu}

Dokumen satu terdiri atas empat bab, yaitu pendahuluan, tujuan pendidikan, struktur dan muatan kurikulum, dan kalender pendidikan. Pada bab I terdiri atas latar belakang, tujuan, dan prinsip-prinsip pengembangan KTSP. Pada bab dua terdiri atas tujuan pendidikan, visi dan misi sekolah, serta tujuan sekolah itu sendiri. Pada bab tiga berisi tentang Stuktur dan muatan kurikulum dan bab empat berisi tentang kalender pendidikan.

b. Struktur Dokumen Dua

Dokumen II berisi tentang Silabus dan Rencana Pelaksanaan Pembelajaran (RPP).

3. KTSP Bahasa Arab

KTSP sebagai kurikulum terbaru menargetkan pada suatu kompetensi yang seharusnya dimiliki oleh siswa. Di dalam KTSP pemerintah hanya memberikan rambu-rambu

4 Devita Rahmawati, "Metode Pembelajaran Bahasa Asing," http://www. devitarahmawati.blogspot.com/2012/01/metode-pembelajaran-bahasa-asing.html

5 Jauhar Ali, "Pembelajaran Bahasa Arab Berbasis Cross Cultural Understanding", http://www. joebukan.blogspot.com. pembelajaran-bahasa-arab-berbasiscross.html 
Standar Isi dan Standar Kelulusan. Adapun dalam Standar Kelulusan ada dua kompetensi yang diharapkan yaitu Standar Kompetensi (SK) dan Kompetensi Dasar (KD). Standar ini dipergunakan sebagai acuan dalam mengembangkan kurikulum bahasa Arab sesuai dengan kebutuhan daerah atau madrasah. Kemudian kurikulum bahasa Arab di madrasah dipersiapkan untuk pencapaian keterampilan dasar awal berbahasa Arab siswa, dengan didukung aspek-aspek kebahasaaan seperti mendengarkan (istima'), berbicara (kalam), membaca (qira'ah) dan menulis (kitabah).

Untuk pencapaian kompetensi di atas dirancang kegiatan pembelajaran bahasa Arab dengan tema-tema tentang kegiatan sehari-hari, seperti tantang aqidah dan ibadah. Di samping itu untuk mendukung tercapainnya kompetensi tersebut guru didorong untuk aktif mendesain silabus dan RPP sedemikian rupa dengan diberikannya kebebasan menggunakan berbagai macam metode serta media pembelajaran bahasa Arab guna tercapainya tujuan pembelajaran bahasa Arab. berikut ini rambu-rambu yang ditetapkan dalam rumusan KTSP mata pelajaran bahasa Arab adalah sebaga berikut:

a. Menerapkan pendekatan kompetensi dengan pola pembelajaran yang dikembangkan menekankan keterpaduan antara tiga lingkungan pendidikan yaitu: lingkungan keluarga, madrasah, dan masyarakat.

b. Penerapan konsep-konsep pembelajaran bahasa Arab di madrasah adalah belajar menggunakan bahasa untuk berkomunikasi, baik lisan maupun tulisan, bukan untuk mendalami struktur kalimat itu sendiri.

c. Memanfaatkan teknologi komunikasi ini dapat berupa media cetak dan elektronika. Media cetak meliputi surat kabar, majalah, buku brosur, dan lain-lain. Sedangkan media elektronika meliputi komputer, televisi, radio internet, VCD, $\mathrm{CD}$, dan lain-lain.

d. KTSP atau silabus dan RPP yang sudah disusun hanya sebagai model yang masih dapat dikembangkan atau diseder- 
hanakan sesuai dengan kondisi siswa. ${ }^{6}$

4. Implementasi KTSP Bahasa Arab

Implementasi KTSP adalah bagaimana menyampaikan pesan-pesan kurikulum kepada peserta didik untuk membentuk kompetensi mereka sesuai dengan karakteristik dan kemampuan masing-masing. ${ }^{7}$ Dengan demikian dapat di simpulkan bahwa yang dimaksud dengan implementasi Kurikulum Tingkat Satuan Pendidikan (KTSP) bahasa Arab adalah bagaimana menyampaikan pesan-pesan kurikulum bahasa Arab kepada peserta didik untuk membentuk kompetensi mereka sesuai dengan karakteristik dan kemampuan masingmasing peserta didik.

5. Faktor-Faktor yang Mempengaruhi Implementasi KTSP Bahasa Arab

Terdapat beberapa faktor yang dapat mempengaruhi implementasi KTSP, hal ini sebagaimana diungkapkan oleh Oemar Hamalik bahwa faktor-faktor yang mempengaruhi implementasi KTSP adalah sebagai berikut:

a. Karakteristik kurikulum, yang mencakup ruang lingkup bahan ajar, tujuan, fungsi, sifat dan sebagainya.

b. Strategi implementasi, yaitu strategi yang digunakan dalam implementasi kurikulum, seperti diskusi profesi, seminar, penataran, lokakarya, penyediaan buku kurikulum, dan berbagai kegiatan lain yang dapat mendorong penggunaan kurikulum di lapangan.

c. Karakteristik pengguna kurikulum, yang meliputi pengetahuan, keterampilan, serta nilai dan sikap guru terhadap kurikulum dalam pembelajaran. ${ }^{8}$

6. Upaya Peningkatan Implementasi KTSP Bahasa Arab ${ }^{9}$

J.G Owen dalam Oemar Hamalik yang dikutip oleh Rino

6 Ibid.

7 Mulyasa, Implementasi Kurikulum Tingkat Satuan Pendidikan, (Jakarta: Bumi Aksara, 2009) hal. 178.

8 Oemar Hamalik, Dasar-dasar Pengembangan Kurikulum, (Bandung: Remaja Rosdakarya, 2008), hal. 239.

9 Rino, "Strategi Implementasi KTSP" http://www.scribd.com/Strategi-Implementasi-Kurikulum-Tingkat-Satuan-Pendidikan.html. 
menyebutkan bahwa berdasarkan faktor-faktor yang dapat mempengaruhi implementasi KTSP, maka dapat ditentukan pendekatan yang digunakan dalam implementasi yang tepat yaitu: tipe perencanaan yang digunakan yaitu topdown dan grass-root, penggunaan strategi implementasi dan supervisi yang dilakukan oleh kepala sekolah dan guru.

a. Tipe Perencanaan yang Digunakan (Topdown dan Grass-Root)

Pada pendekatan administratif, inisiatif pengembangan kurikulum berasal dari para pemegang kebijakan kemudian turun ke stafnya atau dari atas ke bawah (topdown), maka dalam model grass roots, inisiatif pengembangan kurikulum dimulai dari guru-guru sebagai implementator, kemudian menyebar pada lingkungan yang lebih luas (bottom up). Oleh karena sifatnya yang demikian, maka pendekatan ini lebih banyak digunakan dalam penyempurnaan kurikulum (curriculum improvement), walaupun dalam skala yang terbatas mungkin juga digunakan dalam pengembangan kurikulum baru (curriculum construction). Pada model grass-root tugas para administrator dalam pengembangan model ini tidak lagi berperan sebagai pengendali pengembangan akan tetapi sebagai motivator, dan fasilitator. Perubahan atau penyempurnaan kurikulum bisa dimulai guru-guru secara individual atau bisa oleh kelompok guru.

b. Penggunaan Strategi Implementasi KTSP

Untuk mewujudkan implementasi KTSP yang efisien dan efektif perlu dikembangkan strategi khusus yang yang berorientasi pada guru, antara lain:

1) Mengubah mindset guru dari paradigma konvensional ke paradigma abad 21 (baru)

2) Membentuk budaya (kultur) baru di lingkungan sekolah

3) Guru sebagai pengembang kurikulum; Sebagai seorang pengembang kurikulum guru dituntut untuk memiliki pemahaman dan wawasan yang luas tentang kurikulum baik secara teoritis maupun secara praktis.

c. Support Activitas, Supervisi yang dilakukan oleh Kepala Sekolah dan Guru

Supervisi dilakukan oleh kepala sekolah bukan hanya 
untuk guru-guru atau pegawai dalam menjalankan tugas dengan sebaik-baiknya, tetapi kepala sekolah juga berusaha bersama guru-guru bagaimana cara memperbaiki proses belajar mengajar. Dalam kegiatan supervisi guru-guru tidak dianggap sebagai pelaksana pasif, melainkan sebagai partner yang mempunyai ide-ide dan pengalaman-pengalaman yang perlu didengar, dihargai dan diikutsertakan di dalam usahausaha perbaikan pendidikan.

7. Bahasa Arab Sebagai Mata Pelajaran

Bahasa Arab sebagaimana diungkapkan oleh Syaikh Mustafa al-Ghulayani dalam kitabnya Jami'u al-Durus al-Arabiyyah, bahwa bahasa Arab ialah perkataan yang diungkapkan atau yang diujarkan oleh orang-orang Arab untuk maksud tertentu. ${ }^{10}$ Bahasa Arab selain sebagai bahasa Al-Qur'an juga sebagai alat komunikasi; sebagai alat komunikasi bahasa merupakan suatu alat yang sangat penting dalam kehidupan bersosial, dengan bahasa manusia dapat menyampaikan ide maupun pemikirannya. Karenanya bahasa perlu untuk dikaji maupun dipelajari.

Mengingat pentingnya mempelajari bahasa Arab maka sebagian negara besar telah membuka universitas-universitas atau sekolah-sekolah yang mempelajari bahasa Arab. Hal ini sesuai dengan apa yang dituturkan oleh Abdul Aziz dalam bukunya Psikolinguistik Pembelajaran Bahasa Arab bahwa:

[P]ada akhir abad ke-13 atau $19 \mathrm{M}$ yang lalu, dan awal abad ke-14 atau $20 \mathrm{M}$, program pengajaran bahasa Arab untuk non Arab telah dibuka di banyak universitas di negara-negara Arab, dipusat-pusat kegiatan Islam di lembaga-lembaga, di unit-unit khusus (independen), di jurusan-jurusan dalam fakultas sastra, atau fakultas-fakultas bahasa juga telah dibuka programprogram pengajaran bahasa Arab yang diajarkan di beberapa jurusan studi bahasa Arab atau studi ketimuran di universitasuniversitas Barat, Eropa, dan Amerika Serikat. ${ }^{11}$

Lembaga-lembaga pendidikan yang membuka kelas bahasa Arab ini tidak hanya menyiapkan lulusan-lulusan yang

10 Syaikh Mustafa Al-Ghulayani, Jami'u al-Durus al-'Arabiyyah (Beirut: 1973), hal. 4.

11 Abdul Aziz, Psikolinguistik Pembelajaran Bahasa Arab, (Bandung: Humaniora, 2009), hal. 58. 
pandai bahasa Arab saja akan tetapi juga membuka kelas-kelas untuk para siswa yang ingin menjadi pengajar bahasa Arab dengan memberikan ijazah magister dan diploma selain pembekalan sebagai pendidik bahasa Arab.

\section{B. Metode Penelitian}

Penelitian ini menggunakan pendekatan deskriptif kualitatif melalui sudut pandang ilmu pendidikan dengan observasi partisipatif untuk menguraikan, menggambarkan, menggali dan mendeskripsikan implementasi KTSP bahasa Arab di sekolah tersebut.

Setting penelitian ini adalah di MAN Tembilahan Indragiri Hilir Riau dengan subyek penelitian meliputi seluruh elemen yang berhubungan dengan implementasi KTSP Bahasa Arab di MAN Tembilahan. Teknik pengambilan sampel menggunakan purposive sampling dengan metode pengumpulan data melalui observasi partisipasi moderat, wawancara tak berstruktur dan dokumentasi. Sementara untuk menganalisis data dalam penelitian ini adalah metode analisis data mengalir (flow model analysis), yang menurut Miles dan Huberman pada prinsipnya kegiatan analisis data dilakukan sepanjang kegiatan penelitian, dan kegiatan yang paling inti mencakup menyederhanakan data (data reduction), penyajian data (data display), serta menarik kesimpulan (making conclusion). ${ }^{12}$

\section{Hasil Penelitian}

A. Implementasi Kurikulum Tingkat Satuan Pendidikan (KTSP) Bahasa Arab Di MAN Tembilahan Indragiri Hilir Riau

1. Perencanaan Implementasi KTSP Bahasa Arab

Terdapat beberapa komponen yang perlu direncanakan oleh guru bahasa Arab sebelum melaksanakan kegiatan belajar dan mengajar, yakni tujuan yang hendak dicapai, materi (bahan ajar), metode dan alat penilaian.

a. Tujuan yang Hendak Dicapai

Tujuan pembelajaran adalah suatu cita-cita yang ingin

12 Matthew B. Miles dan A. Michael Huberman. Terj., Analisis Data Kualitatif (Jakarta: UI Press, 2007), hal. 16-20. 
dicapai dalam kegiatan belajar dan mengajar. Untuk mencapai tujuan pembelajaran nasional, perlu disusun tujuan pembelajaran tingkat semester, mid semester dan tiap kali tatap muka. Hal ini sebagaimana yang tercantum di dalam SK dan KD berikut: SK: [M]ampu berkomunikasi secara lisan dan tertulis dengan menggunakan bahasa Arab Fusha dengan lancar dan akurat. KD: membaca, memahami, حوار berbicara dan menulis dalam insya' muwajjah tentang dan قراءة dengan struktur kalimat yang mengandung ben-

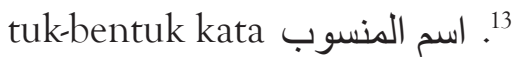

Berdasarkan dokumen di atas diketahui bahwa guru bahasa Arab dalam mencapai tujuan pembelajaran perlu mengembangkan dari SK dan KD menjadi indikator hasil belajar. Selain itu diketahui bahwa dalam kegiatan pembelajaran bahasa Arab guru dituntut untuk mampu membentuk anak didik memiliki sejumlah kompetensi dalam berbahasa Arab seperti kompetensi menyimak, kompetensi berbicara, kompetensi membaca dan kompetensi menulis.

RPP guru bahasa Arab menyebutkan bahwa terdapat beberapa kompetensi yang dapat dicapai dalam kegiatan pemebelajaran bahasa Arab, yakni kompetensi menyimak, kompetensi membaca, dan kompetensi menulis bahasa Arab. ${ }^{14}$ Dengan demikian diketahui bahwa terdapat tujuan pembelajaran bahasa Arab yang belum disusun guru bahasa Arab, yakni kompetensi berbicara bahasa Arab.

Dalam penyusunan tujuan pembelajaran guru hendaknya menjabarkan SK dan KD kedalam tujuan-tujuan pembelajaran yang mampu mendukung tercapainya tujuan pembelajaran sebagaimana yang ditetapkan dalam Standar Isi dan Standar Kompetensi yakni penguasaan empat kompetensi dalam berbahasa Arab yakni siswa mampu menyimak teks yang diperdengarkan, berkomunikasi dengan bahasa Arab, mampu membaca teks bahasa Arab dan mampu menulis bahasa Arab baik dengan melihat maupun dengan

13 Dokumentasi, 28 Maret 2013.

14 Dokumentasi, 28 Maret 2013. 
metode imla'.

b. Materi Pembelajaran Bahasa Arab (Bahan Pelajaran Bahasa Arab)

Berdasarkan RPP guru bahasa Arab dijelaskan bahwa bahwa penyusunan materi pembelajaran dan tujuan pembelajaran bahasa Arab menekankan pemahaman konsep dan pencapaian kompetensi membaca. Hal ini terlihat dari pemilihan materi tentang qira'ah dan qa'idah nahwiyah dan sharfiyah dalam beberapa pertemuan. ${ }^{15}$ Sementara itu buku yang digunakan dalam pembelajaran bahasa Arab, guru ber16.10 تعليم اللغة العربية puku pegangan guru

Dalam merumuskan materi pelajaran guru harus mengacu pada tujuan pembelajaran, di mana tujuan pembelajaran nantinya dirumuskan guna mencapai tujuan pendidikan semester dan ahirnya dapat mendukung tercapainya tujuan pendidikan secara nasional dan dalam penyusunan materi pembelajaran bahasa Arab, guru bisa menggali dari berbagai sumber dengan mengacu pada SK dan KD yang harus di capai oleh anak didik.

c. Metode Pembelajaran Bahasa Arab

Guru senantiasa dituntut keprofesionalannya untuk menentukan metode yang tepat dengan menyesuaikan materi pembelajaran sebelum materi disampaikan kepada anak didik. Berdasarkan dokumentasi diketahui bahwa guru bahasa Arab telah merumuskan metode ceramah, tanya jawab, diskusi, penguasaan dan kerja kelompok dalam beberapa RPP yang telah dirumuskan, sementara hasil wawancara penulis dengan $\mathrm{T}$ sebagai berikut: Biasanya bapak mengajar dengan metode ceramah, membaca, latihan, dan kadangkadang diskusi yakni mendiskusikan makna mufradat yang terdapat di dalam qira'ah. ${ }^{17}$

Dengan demikian dapat diketahui bahwa metode pembelajaran yang disusun guru bahasa Arab adalah metode ce-

15 Observasi, 7 Juni 2013.

16 Observasi, 7 Juni 2013.

17 Wawancara, 12 April 2013. 
ramah, tanya jawab, diskusi, penguasaan dan kerja kelompok. Dengan demikian diketahui bahwa metode yang telah disusun guru bahasa Arab belum mendukung tercapainya tujuan pembelajaran bahasa Arab yakni guru belum merumuskan metode yang mampu mendukung tercapainya tujuan pembelajaran bahasa Arab seperti penggunaan metode percakapan (thariiqah al-hiwaariyyah) guna mengasah kompetensi percakapan anak didik untuk dapat berkomunikasi dengan bahasa kedua, dan metode imla' guna mengasah kemampuan anak didik untuk mengasah kemampuan anak didik dalam menulis bahasa Arab dengan cara dikte.

Dalam merumuskan metode pembelajaran hendaknya guru memilih serta menggunakan metode pembelajaran yang tepat sesuai dengan materi dan kondisi anak didik. Selain itu metode pembelajaran hendaknya mampu memotivasi anak didik untuk belajar bahasa arab dengan menciptakan lingkungan pembelajaran yang kondusif dan produktif serta mampu mengakomodasikan berbagai perbedaan katakteristik anak didik. Dengan pemilihan metode yang tepat diharapkan guru bahasa Arab akan mudah dalam pencapaian tujuan pembelajaran bahasa Arab sehingga diharapkan dapat tercipta lingkungan pembelajaran bahasa Arab yang aktif. kreatif, efektif dan menyenangkan.

d. Media

Berdasarkan hasil wawancara, dokumentasi dan observasi penulis di MAN Tembilahan diketahui bahwa diantara media yang dapat dimanfaatkan dalam kegiatan pembelajaran bahasa Arab adalah media internet, TV, VCD, Tip, media gambar, buku قاموس محمود يونس, تعليم اللغة العربية , papan tulis, spidol, dimana media ini bisa dimanfaatkan di dalam kegiatan belajar dan mengajar. Sementara media yang biasa direncanakan guru bahasa Arab dalam RPP adalah media audio visual, lingkungan sosial, guru, siswa buku قاموس محمود يونس dan تعليم اللغة العربية.

Dengan demikian diketahui bahwa dalam perencanaan media pembelajaran bahasa Arab, guru bahasa Arab belum menggunakan media yang variatif. Selain itu diketa- 
hui bahwa guru bahasa Arab belum memanfaatkan media pembelajaran yang tersedia di MAN Tembilahan sebagai media pembelajaran bahasa Arab karena berdasarkan data wawancara penulis diketahui bahwa guru bahasa Arab belum memahami pemanfaatan media elektronik seperti internet, TV, maupun VCD.

Dalam memilih dan menentukan media pembelajaran bahasa Arab, hendaknya guru dapat memilih media yang mampu menibulkan gairah atau semangat belajar disamping harus memperhatikan segi kemampuan dalam pemanfaatan media guru harus memilih dan menggunakan media yang memiliki manfaat dalam mendukung tercapainya tujuan pembelajaran bahasa Arab.

e. Alat penilaian

Berdasarkan wawancara dan dokumentasi di yang penulis peroleh dari guru bahasa Arab di MAN Tembilahan, diketahui bahwa penilaian yang dirumuskan guru bahasa Arab dalam RPP adalah penilaian kompetensi menyimak, kompetensi membaca dan kompetensi menulis. Dengan demikian diketahui bahwa penilaian yang rumuskan guru bahasa Arab dalam RPP belum mampu mengukur kompetensi bahasa Arab secara komprehensif, yakni guru belum memasukkan penilaian kompetensi berkomunikasi bahasa Arab.

Untuk mengetahui ketercapaian tujuan pembelajaran bahasa Arab hendaknya penilaian mengacu kepada empat kompetensi yang telah ditetapkan di dalam SKL yakni siswa mampu menyimak, berkomunikasi, membaca dan menulis dengan bahasa Arab, karena itulah alat penilaian perlu disusun terlebih dahulu sebelum guru melakukan proses belajar dan mengajar.

2. Pelaksanaan Implementasi KTSP Bahasa Arab

Pelaksanaan kegiatan belajar dan mengajar bahasa Arab pada umumnya mencakup tiga kegiatan yakni, kegiatan pembukaan, kegiatan inti dan kegiatan penutup.

a. Kegiatan Pembukaan

Berdasarkan wawancara dan dokumentasi diketahui 
bahwa guru bahasa Arab mengawali kegiatan pembelajaran bahasa Arab dengan membaca doa bersama dilanjutkan dengan penjelasan mengenai kompetensi yang harus dicapai setelah selesai pembelajaran bahasa Arab. Berdasarkan observasi penulis di kelas XI MAK diketahui bahwa siswa membaca doa bersama dengan tenang, setelah itu siswa menyimak penjelasan guru bahasa Arab tentang-tujuan pembelajaran yang akan dicapai dalam pembelajaran bahasa Arab. ${ }^{18}$ Di samping itu berdasarkan observasi penulis dikesempatan yang lain di kelas XI MAK Tembilahan diketahui bahwa guru bahasa Arab memulai kegiatan pembelajaran dengan salam dan dilanjutkan mengabsen siswa, setelah itu meminta beberapa siswa untuk membaca qira'ah dengan terjemahannya, dimana materi qira'ah itu telah diterjemahkan pada pertemuan sebelumnya. ${ }^{19}$

Berdasarkan data di atas, diketahui bahwa guru bahasa Arab dalam membuka kegiatan pelajaran bahasa Arab di MAN Tembilahan Indragiri Hilir Riau tidak terpaku pada satu macam jenis kegiatan, dalam hal ini guru memvariasikan strategi dalam membuka pelajaran. Dengan demikian di ketahui bahwa kegiatan pendahuluan seperti membaca doa dan penjelasan terhadap kompetensi yang harus dicapai siswa setelah mengikuti kegiatan pembelajaran bahasa Arab merupakan kegiatan yang penting guna memusatkan perhatian anak didik ke dalam pembelajaran bahasa Arab.

b. Kegiatan Inti

Berdasarkan data observasi, wawancara dan dokumentasi yang penulis kumpulkan diketahui bahwa pelaksanaan kegiatan belajar dan mengajar bahasa Arab berlangsung dengan tenang, siswa mengikuti materi yang disampaikan guru bahasa Arab, namun pelaksanaan pembelajaran bahasa Arab di MAN Tembilahan Indragiri Hilir Riau diketahui belum efektif hal ini terlihat pada kegiatan-kegiatan yang belum mampu mendukung tercapainya tujuan pembelajaran bahasa Arab seperti pembentukan kompetensi berkomuni-

18 Observasi, 19 April 2013.

19 Observasi, 7 Juni 2013. 
kasi bahasa Arab praktis dan kompetensi menulis dengan metode imla'. Selain itu diketahi dalam pelaksanaan implementasi KTSP guru terlihat tidak menggunakan metode pembelajaran yang variatif dengan menggunakan metode ceramah, kerja kelompok, penugasan tanya jawab, qawa'id wa tarjamah, dan qira' dalam beberapa pertemuan. Adapun penggunaan media pembelajaran bahasa Arab, guru belum memanfaatkan media pembelajaran yang tersedia di MAN hal ini diketahui karena kurangnya penguasaan guru dalam penggunaan media elektronik seperti internet, TV, VCD.

Dengan demikian diketahui bahwa dalam kegiatan inti, pembentukan kompetensi yang dilakukan guru bahasa Arab adalah kompetensi membaca, menterjemah dan kompetensi pemahaman kaidah nahwiyah sebagi pendukung siswa dalam memahami teks bahasa Arab. Berdasarkan data di atas pula dapat penulis fahami bahwa RPP memiliki peranan penting dalam implementasi kurikulum. Sebaik apapun pemahaman guru mengenai materi yang akan diajarkan tanpa perencanaan yang baik maka hasilnya kurang optimal, sebaliknya perencanaan yang baik tanpa didukung dengan penguasaan materi yang baik tentu akan menghasilkan pemahaman-pemahaman yang kabur terhadap anak didik.

c. Penutup

Pada kegiatan penutup hendaknya guru mengetahui pembentukan kompetensi yang telah dimiliki anak didik serta pencapaian tujuan pembelajaran yang telah dicapai dalam KBM.

Berdasarkan hasil observasi penulis di kelas XI MAK Tembilahan Indragiri Hilir Riau diketahui bahwa penilaian yang berlangsung di MAN Tembilahan adalah guru meminta anak didik untuk membaca materi qira'ah dengan terjemahan bahasa Indonesianya, meminta siswa untuk menjawab soal-soal yang ada di dalam buku تعليم اللغة العربية baik secara lisan maupun tulisan dan menulis bahasa Arab dengan cara mencari kata-kata yang mengandung kaidah nahwiyah atau sharfiyah seperti hamzah washal dan hamzah qatha' di 
dalam qira'ah. ${ }^{20} \mathrm{Hal}$ ini sesuai dengan hasil wawancara penulis dengan NW sebagai berikut: Setelah menterjemahkan qira'ah biasanya bapak menjelaskan isi kandungan materi qira'ah kemudian meminta kami untuk membaca dengan terjemahannya sampai jam pelajaran habis dan kadangkadang kami diminta untuk mengisi soal-soal yang ada di dalam buku 21 تعليم اللغة العربية

Berdasarkan data di atas diketahui bahwa untuk mengetahui tingkat pencapaian pembelajaran bahasa Arab guru meminta anak didik untuk membaca, menjawab soal-soal baik secara lisan maupun tulisan, dan menuliskan kalimatkalimat yang mengandung kaidah nahwiyah dengan cara mencari di dalam qira'ah yang telah diajarkan.

Dengan demikian diketahui bahwa terdapat penilaian yang belum di susun dalam RPP dan diimplementasikan dalam kegiatan pembelajaran bahasa Arab seperti kompetensi berkomunikasi bahasa Arab dan kompetensi menulis secara imla'. Dengan demikian diketahui bahwa implementasi KTSP bahasa Arab di MAN Tembilahan Indragiri Hilir Riau Kelas XI MAK baik secara dokumentatif maupun implementasi masih belum dikembangkan, yakni dengan pemilihan dan penggunaan materi, media, metode serta strategi yang variatif dan alat evaluasi yang dapat mengukur secara komprehensif.

3. Evaluasi Implementasi KTSP Bahasa Arab

Evaluasi dilakukan untuk mengetahui keberhasilan suatu tujuan dalam pembelajaran bahasa Arab. Evaluasi merupakan suatu proses mempertimbangkan untuk memberikan nilai terhadap sesuatu yang dinilai. Untuk mendapatkan penilaian guru bahasa Arab perlu mengadakan pengukuran melalui tes. Terdapat empat kompetensi yang harus dimiliki siswa dan dinilai dalam pembelajaran bahasa Arab yakni kompetensi menyimak (istima'), kompetensi berbicara (kalam), kompetensi membaca (qira'ah), dan kompetensi menulis (kitabah).

20 Observasi, 23 Mei 2013.

21 Wawancara, 23 Mei 2013. 
Berdasarkan observasi di MAN Tembilahan, diketahui bahwa guru bahasa Arab memberikan penilaian dalam bentuk tes maupun non tes. Penilaian dalam bentuk tes telihat pada saat guru bahasa Arab meminta siswa menjawab soal-soal dari buku تعليم اللغة العربية dan membaca teks bahasa Arab, sementara penilaian dalam bentu non tes terlihat dari keaktifan maupun keterlibatan siswa pada saat berdiskusi.

Berdasarkan data di atas, di ketahui bahwa penilaian pembelajaran bahasa Arab di MAN Tembilahan belum sepenuhnya mengacu pada pencapaian kompetensi berbahasa Arab, yakni dengan menilai ke-empat kompetensi dalam berbahasa Arab yakni kompetensi menyimak, kompetensi berbicara, kompetensi membaca dan kompetensi menulis.

Dengan demikian diketahui bahwa penilaian pembelajaran yang ideal adalah penilaian yang dapat mengukur seluruh kompetensi yang harus dimiliki pada suatu mata pelajaran seperti dalam pembelajaran bahasa Arab, kompetensi yang harus dicapai adalah kompetensi menyimak, kompetensi berbicara, kompetensi membaca dan kompetensi menulis. Dengan demikian dapat pula diketahui bahwa implementasi yang dilakukan guru bahasa Arab di MAN Tembilahan Indragiri Hilir Riau terhadap mata pelajaran bahasa Arab belum efektif, yakni belum terciptanya lingkungan pembelajaran yang dapat mendukung tercapainya tujuan pembelajaran, sehingga belum tercapainya tujuan pembelajaran bahasa Arab seperti siswa terlihat belum mampu untuk berkomunikasi dengan bahasa Arab praktis dalam kegiatan belajar dan mengajar bahasa Arab dan siswa belum menguasai kompetensi menulis secara dikte (imla').

\section{B. Faktor-faktor Implementasi Kurikulum Tingkat Satuan Pendidikan (KTSP) Bahasa Arab}

1. Faktor Pendukung a. Faktor Sarana dan Prasarana

Terdapat beberapa sarana pembelajaran bahasa Arab yang dapat dimanfaatkan guru bahasa Arab guna mencapai tujuan pembelajaran bahasa Arab, namun baik secara do- 
kumentasi maupun implementasi guru bahasa Arab belum memanfaatkan sarana pembelajaran bahasa Arab yang tersedia di MAN Tembilahan Indragiri Hilir Riau. ${ }^{22}$

Berkenaan dengan sarana dan prasarana pembelajaran bahasa Arab di MAN M menyebutkan: sarana pembelajaran yang ada di MAN Tembilahan sangat mendukung dalam pelaksanaan kegiatan belajar dan mengajar bahasa Arab, namun Saya belum terbiasa menggunakan internet, komputer ataupun VCD dalam kegiatan pembelajaran bahasa Arab. ${ }^{23}$

b. Faktor Motivasi Belajar Siswa Terhadap Mata Pelajaran Bahasa Arab

Siswa kelas XI MAK memiliki motivasi untuk belajar bahasa Arab, sehingga memudahkan bagi guru untuk dapat menyampaiakan materi pembelajaran bahasa Arab. Hal ini sesuai dengan hasil wawancara penulis dengan KA sebagai berikut: Menurut saya pelajaran bahasa Arab tidak begitu sulit saya suka dengan pelajaran bahasa Arab, karena bahasa Arab merupakan bahasa al-Qur'an, selain itu banyak sumber pelajaran agama Islam berasal dari bahasa Arab. ${ }^{24}$

Dengan demikan dapat diketahui bahwa dalam kegiatan pembelajaran bahasa Arab, motivasi merupakan salah satu faktor penting untuk dapat mencapai tujuan pembelajaran, akan tetapi faktor motivasi perlu didukung dengan pemilihan dan penggunaaan metode, media, starategi, alat evaluasi yang dapat mengukur dan pemilihan materi yang dapat mendukung pembentukan kompetensi siswa. Hal ini guna mengefektifkan serta memudahkan siswa dan guru dalam mencapai tujuan pembelajaran bahasa Arab.

2. Faktor Penghambat

a. Latar Belakang Siswa

Berdasarkan wawancara penulis dengan guru bahasa arab MAN Tembilahan Indragiri Hilir Riau diketahui bahwa siswa kelas XI MAK berlatar belakang pendidikan MTS

22 Observasi, 7 Juni 2011.

23 Wawancara, 9 Juni 2013.

24 Wawancara, 26 April 2013. 
dan SMP. Hal ini sebagaimana wawancara penulis dengan M sebagai berikut: Latar belakang pendidikan siswa kelas XI MAK rata-rata MTs dan sebagian kecil SMP. ${ }^{25}$

Berdasarkan wawancara di atas dapat diketahui bahwa siswa kelas XI MAN Tembilahan Indragiri Hilir Riau memiliki latar belakang pendidikan bahasa Arab yang heterogen yang berakibat pada heterogenitas kemampuan mereka dalam mengikuti pelajaran bahasa Arab. Siswa yang berasal dari MTs umumnya memiliki kemampuan dasar dalam berbahasa Arab karena di MTs mereka telah mempelajari bahasa Arab apalagi didukung dengan pendidikan keluarga islami yang tidak terpisah dengan bahasa Arab. Sementara itu siswa yang tidak memiliki latar belakang pendidikan bahasa Arab, kemampuan bahasa Arab mereka terbatas pada kemampuan membaca al-Qur'an tanpa diiringi dengan kemampuan menulis huruf Arab. Ketika mereka melanjutkan pendidikan pada jenjang yang lebih tinggi, mereka mengalami kesulitan dalam mengikuti pelajaran, terutama karena mereka harus berada satu kelas dengan siswa yang memliki latar belakang bahasa Arab yang lebih baik.

Menyikapi latar belakang pendidikan bahasa Arab siswa kelas XI yang heterogen diperlukan strategi dengan penggunaan media dan metode pembelajaran yang tepat. Dengan penggunaaan strategi, media dan metode yang tepat didukung pemilihan materi yang sesuai dengan kemampuan anak didik diharapkan siswa dapat memahami materi yang sampaikan oleh guru bahasa Arab.

b. Latar Belakang Pendidikan Guru dan Kompetensi Guru dalam Pengembangan RPP

Berdasarkan wawancara penulis, disebutkan bahwa latar belakang pendidikan guru bahasa Arab adalah Jurusan Sastra Arab Fakultas Adab. latar belakang pendidikan merupakan sarat utama dalam menentukan suksesnya implementasi KTSP. Terdapat beberapa komponen kurikulum yang sudah tersusun di dalam RPP guru bahasa Arab, yakni komponen tujuan, komponen materi, komponen me-

25 Wawancara, 16 Mei 2013. 
dia dan komponen alat evaluasi, namun diketahui belum dikembangkan dengan baik, baik dari komponen tujuan, komponen materi, komponen media dan komponen alat evaluasi. ${ }^{26}$

Berdasarkan dokumentasi, penyusunan RPP sudah sesuai sebagaimana dicontohkan di dalam KTSP, baik dari segi format maupun komponen RPP, namun dalam segi kontennya belum dikembangkan dengan baik, baik dalam segi pemiliham materi yang menekankan aspek pencapaian kompetensi membaca dan kompetensi tata bahasa, penetapan tujuan pembelajaran yang tidak dapat mendukung pencapaian kompetensi, pemiliham media dan metode yang monoton, dan alat evaluasi yang belum dapat mengukur kompetensi kebahasaan.

Secara dokumentatif guru bahasa Arab telah menyusun RPP sesuai dengan model KTSP baik dari segi format maupun komponen RPP, namun dari segi kontennya belum dikembangkan dengan baik, dan secara implementasi guru bahasa Arab menggunakan RPP sebagai panduan dalam kegiatan pembelajaran bahasa Arab. Dengan demikian dapat diketahui bahwa kemampuan guru bahasa Arab dalam menyusun RPP dan mengimplementasikan KTSP dipengaruhi oleh latar belakang pendidikan guru bahasa Arab, dimana M berlatar belakang pendidikan Sastra Arab, dan hal ini mempengaruhi guru bahasa Arab dalam menyusun RPP dan mengimplementasikannya dalam kegiatan belajar dan mengajar.

\section{Upaya Peningkatan Implementasi KTSP Bahasa Arab Di MAN Tembilahan Indragiri Hilir Riau}

1. Peningkatan Profesionalisme Guru Bahasa Arab

Wawancara penulis dengan $\mathrm{M}$ sebagai berikut: upaya yang saya lakukan untuk meningkatkan profesionalisme sebagai tenaga pendidik adalah dengan mengikuti pelatihanpelatihan kompetensi guru, sertifikasi, dan melanjutkan studi

26 Dokumentasi, 28 Maret 2013. 
untuk guru. Dalam hal ini saya sedang proses tesis. ${ }^{27}$

Berdasarkan data di atas dapat diketahui bahwa terdapat beberapa upaya yang telah dilakukan guru bahasa Arab untuk meningkatkan profesionalismenya yakni dengan mengikuti pelatihan, sertifikasi dan melanjutkan pendidikan program S2. Jika menilik dari segi latar belakang pendidikan guru, diketahui bahwa guru bahasa Arab telah melakukan upaya-upaya untuk mengefektifkan implementasi kurikulum, namun pada prakteknya belum sepenuhnya dapat terimplementasi, baik kurikulum dalam segi dokumen maupun kurikulum dalam segi implementasi.

2. Mengusulkan Pengadaan tes Masuk jurusan

Selain memberikan pendidikan Agama Islam, MAN Tembilahan Indragiri Hilir Riau merupakan salah satu lembaga pendidikan yang memberikan program kelas IPA, IPS dan MAK bagi kelas XI dan XII, untuk memasuki kelas IPA, IPS dan MAK perlu diadakan tes masuk jurusan hal ini bertujuan agar siswa dapat mengkuti kegiatan belajar dan mengajar sesuai dengan minat serta kemampuan siswa. Untuk mengatasi latar belakang siswa yang heterogen, guru bahasa Arab mengusulkan akan adanya tes masuk jurusan bagi MAK maupun IPA dan IPS. Dengan demikian dapat diketahui bahwa tes untuk penempatan jurusan memang diperlukan siswa dan guru guna dapat menempatkan siswa sesuai dengan minat dan kemampuan siswa. Selain itu tes ini akan berguna bagi guru guna memudahkan guru dalam merencanakan serta mengimplementasikan KTSP bahasa Arab.

\section{Kesimpulan Dan Rekomendasi}

\section{A. Kesimpulan}

Berdasarkan beberapa kajian yang telah penulis jabarkan dari bab I sampa bab V dapat penulis simpulkan sebagai berikut:

1. Implementasi KTSP bahasa Arab di MAN Tembilahan belum berjalan dengan optimal karena secara dokumentatif, guru baha Arab sudah menyusun silabus dan RPP namun belum dikem-

27 Wawancara, 9 Juni 2013. 
bangkan dengan baik, baik dari segi tujuan pembelajaran, materi pembelajaran, media, metode, maupun alat evaluasinya. Sementara itu secara implementatif, guru bahasa Arab menggunakan RPP dalam pelaksanaan kegiatan belajar dan mengajar namun dalam pelaksanaanya guru belum menciptakan lingkungan pembelajaran yang aktif, kreatif, efektif dan menyenangkan, dan tujuan pembelajaran bahasa Arab belum mencapai hasil yang optimal yakni siswa belum mampu berbicara bahasa Arab praktis dan menulis bahasa Arab dengan metode imla'.

2. Faktor pendukung implementasi KTSP di MAN Tembilahan adalah tersedianya sarana dan prasarana pembelajaran bahasa Arab seperti adanya internet, TV,VCD, TIP, dan media gambar. Adapun faktor penghambat adalah kurangnya penguasaan guru untuk mengembangkan RPP dan di implementasikan dalam proses belajar dan mengajar.

3. Upaya yang telah dilakukan guru bahasa Arab untuk mengefektifkan implementasi KTSP di MAN Tembilahan adalah dengan mengikuti sertifikasi, pelatihan-pelatihan maupun workshop dan melanjutkan pendidikan ke jenjang yang lebih tinggi yaitu strata dua (S2) sesuai dengan bidang yang di ajarkan.

\section{B. Rekomendasi}

Dari hasil Penelitian ini penulis merekomendasikan kepada pihak-pihak terkait berikut dibawah ini:

1. Kepala Sekolah

Hendaknya kepala sekolah tidak hanya mengawasi pelaksanaan KTSP dari segi dokumen saja akan tetapi juga mengawasi pelaksanaan kegiatan belajar dan mengajar di kelas.

2. Guru bahasa Arab

Hendaknya guru bahasa Arab merencanakan pelaksaan pembelajaran terlebih dahulu dengan memilih serta menggunakan metode yang variatif serta media pembelajaran sesuai dengan materi pembelajaran. Selain itu hendaknya guru bahasa Arab mempersiapkan terlebih dahulu alat penilaian yang dapat mengukur serta dapat mendukung tercapainya tujuan pembelajaran bahasa Arab.

3. Kepala Dinas Departemen Agama Daerah Tembilahan 
Hendaknya Kepala dinas Depag senantiasa memberikan pengawasan tidak hanya memberikan pengawasan dalam bentuk dokumen akan tetapi mengawasi guru secara langsung dalam kegiatan belajar dan mengajar. Hal ini bisa dilakukan dengan dengan melalui CCTV, melalui CCTV ini diharapkan bisa dilakukukan perbaikan maupun peningkatan kegiatan belajar dan mengajar bahasa Arab, baik dari segi pemilihan materi, metode, media, alat evaluasi dan hal-hal lain yang berkaitan dengan pencapaian tujuan pembelajaran bahasa Arab.

\section{Daftar Pustaka}

Abdul Aziz. Psikolinguistik Pembelajaran Bahasa Arab. Bandung: Humaniora, 2009.

Abdul Wahab Rosyidi. Media Pembelajaran Bahasa Arab. Malang: UIN Malang Press, 2009.

Departemen Pendidikan Nasional. Peraturan Menteri Pendidikan Nasional Republik Indonesia. Jakarta: Tp. 2006.

Departemen Pendidikan Nasional. Peraturan Menteri Pendidikan Nasional Republik Indonesia. Jakarta: Tp. 2006.

Devita Rahmawati, "Metode Pembelajaran Bahasa Asing," http:// www. devita-rahmawati.blogspot.com/2012/01/metode-pembelajaran-bahasa-asing.html. (diakses pada 21 Januari 2012).

E. Mulyasa. Implementasi Kurikulum Tingkat Satuan Pendidikan. Jakarta: Bumi Aksara, 2009.

Jauhar Ali, "Pembelajaran Bahasa Arab Berbasis Cross Cultural Understanding", http://www. joebukan.blogspot.com. pembelajaran-bahasa-arab-berbasis-cross.html (diakses pada 31 Agustus, 2011).

Matthew B. Miles dan A. Michael Huberman. Terj. Analisis Data Kualitatif. Jakarta: UI Press, 2007.

M. Abdul Hamid. Mengukur Kemampuan Bahasa Arab. Malang: UIN Maliki Press, 2010.

..... Uril Basaruddin dan Bisri Mustofa. Pembelajaran Bahasa Arab. Malang: UIN Malang Press. 2008. 
$40 \frac{\text { Jurnal AL-AFKAR }}{\text { Vol. III, No. II, Oktober } 2014}$

Mustafa Al-Ghulayani. Jami'u al-Durus al-'Arabiyyah. Beirut: 1973.

Muhbib Abdul Wahab. Epistemologi dan Metodologi Pembelajaran Bahasa Arab. Jakarta: UIN Syarif Hidayatullah, 2008.

Oemar Hamalik. Dasar-dasar Pengembangan Kurikulum. Bandung: Remaja Rosdakarya, 2008.

Rino. "Strategi Implementasi KTSP" http://www.scribd.com/ Strategi-Implementasi-Kurikulum-Tingkat-Satuan-Pendidikan. html. (diakses pada 24 Oktober 2012).

Wina Sanjaya. Kurikulum dan Pembelajaran. Jakarta: Kencana, 2008 